\title{
Developing Application Android Based For Japanese Language Learning
}

\author{
B Kurniawan ${ }^{1}$, A Novita $^{2 *}$ \\ \{bobi@unikom.ac.id ${ }^{1}$, atris.novita.26@ mahasiswa.unikom.ac.id ${ }^{2}$ \} \\ Departemen Teknik Elektro, Universitas Komputer Indonesia, Indonesia ${ }^{1}$, \\ Departemen Sastra Jepang, Universitas Komputer Indonesia, Indonesia ${ }^{2}$
}

\begin{abstract}
The purpose of this study is to describe the use of Japanese language learning applications and use them in everyday life. The use of technology is very fast, encouraging every individual to use technology in everyday life, including the use of Japanese. Learning Japanese directly has experienced some difficulties, especially in understanding each word and phrase that is used; it needs help to understand Japanese language learning with the help of media applications. The method used in this study is a descriptive approach to analyze the variables used in application development. The application you normally learn requires compaction of materials to make it easier for application users. Using the application to learn Japanese is expected to be able to produce users who can learn to use Japanese in their daily lives. With the presence of the Japanese language learning application based on the Android operating system, it is expected to produce users who learn Japanese wherever and whenever through the application.
\end{abstract}

Keywords: Application, android, learning.

\section{Introduction}

Android is a Linux-based operating system that has a function for touch screen computers [1]. This Android is direct; it means that the use of Android is followed by movements such as sliding, pinching, and tapping to perform screen and virtual movements to type [2].

An example is that the Japanese language learning application, Akebi. Akebi is an Androidbased offline application that contains and provides Japanese features such as Kanji letters based on their level, injection method, number of scratches, Kunyomi and Onyomi readings, and the meaning of the Kanji letter itself. Kunyomi is a way of mentioning Japan and Onyomi is a Chinese way of reading. Although the application is an offline application, the feature that allows you to access it easily can help teachers and students who are learning Japanese by recognizing the Kanji letters. Therefore, the teachers and students who are still confused about Kanji letters, do not need to buy lots of starch letters. Only by downloading it with the internet, now we can get the application for free, easily, and quickly without spending much money. Also, it can reach a wide audience [3].

Previously, some studies were conducted, such as Research to improve students' ability in ICT technology using the collaboration of mobile augmented reality (CoMARLA) applications [4,5]. Research into the development of Android applications in business in India [6]. Use of an Android-based application for tutorials and design development at Zarqa University [7]. Research and development of mobile applications at Nanjing University [8], Developing 
android-based learning applications with the aim to provide students and teachers in cellular learning [9], Research on Android-based smartphone applications to develop conceptual understanding [10], Developing E-class based E-Learning applications [11], Designing learning applications for Blackberry [12], and Development of educational applications to increase education for students using an android base.

In this study, the focus was on developing an Android-based application for learning Japanese. Hence, creating an application can be useful for users who want to learn Japanese independently. The development of application that focuses on compacting each word used in Japanese helps the learning process for users. The purpose of this study is to be able to use Japanese language learning applications in everyday life. The method used in this study is a descriptive approach that analyzes the variables used in application development.

\section{Method}

The method used is a literary learning system, data analysis, and system design. With this study, we can find out how easy it is to make an application to learn Japanese based on Android and it is useful to learn Japanese using the application we also will make words to find information in English accurately and apply it in daily life.

\section{Results and Discussion}

This Japanese language learning application called AKEBI, with some of the features menus. Figure 1 shows the main menu on the application AKEBI. 


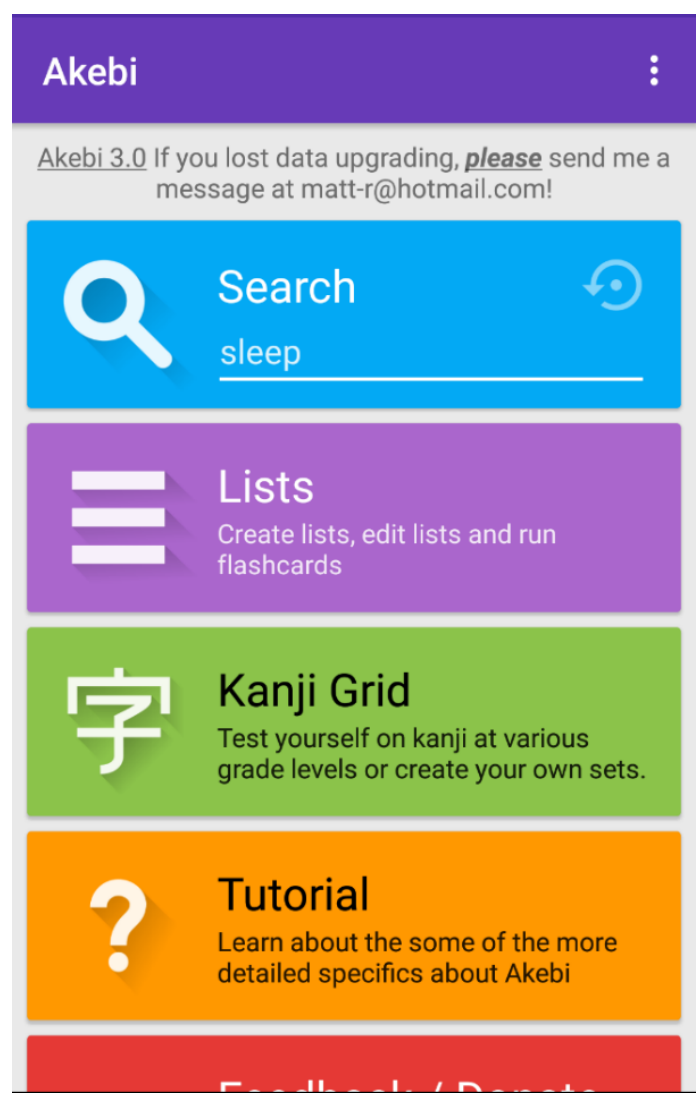

Fig 1. Main Menu. Figure was adapted from Akebi App on Aug 19th, 2018.

In Figure 1, the main menu is designed in more colorful to make it more interesting. There are a few menus in the view of the main menu, i.e. search, lists, Kanji grid, tutorials, and feedback. All menus are displayed in the language of the United Kingdom. The use of application AKEBI tends to lead to the kanji with a comparison to patterns of a sentence because this application is enabled for a search on the vocabulary or the meaning of each kanji.

On the Search menu in Figure 2, there are a search box and Handwriting. This search box can be filled with English or Japanese because automatically, the application will immediately respond to the words and display the results as shown in Figure 3. However, the lack of this feature is the processing of the word to search for Kanji characters using Roman letters will be quite difficult. 


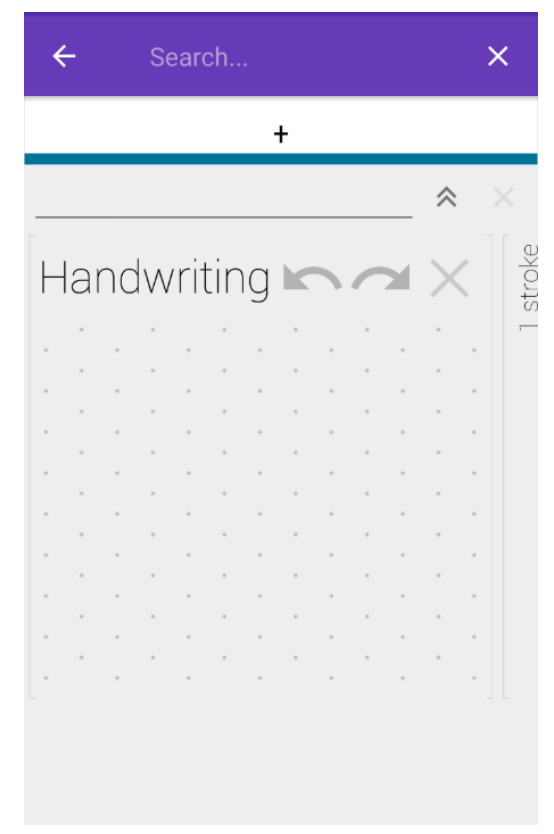

Fig 2. Search Menu. Figure was adapted from Akebi App on Aug 19th, 2018.

\begin{tabular}{|c|c|c|c|c|c|}
\hline \multicolumn{6}{|c|}{$\leftarrow \quad$ sleep } \\
\hline $\mathrm{S}$ & え & え & $\mathrm{p}$ & & + \\
\hline \multicolumn{6}{|c|}{ Translation } \\
\hline \multicolumn{2}{|c|}{$\begin{array}{c}\text { nemuru } \\
\text { ねむる } \\
\text { 眠る } \\
\text { to sleep; to die }\end{array}$} & \multicolumn{2}{|c|}{$\begin{array}{l}\text { suimin } \\
\text { すいみん } \\
\text { 睡眠 } \\
\text { sleep }\end{array}$} & \multicolumn{2}{|r|}{$\begin{array}{l}\text { nemuri } \\
\text { ねむり } \\
\text { 眠り } \\
\text { sleep, sleeping }\end{array}$} \\
\hline \multicolumn{3}{|c|}{$\begin{array}{c}\text { suiminbusoku } \\
\text { すいみんぶそく } \\
\text { 睡眠不足 } \\
\text { lack of sleep }\end{array}$} & \multicolumn{3}{|c|}{$\begin{array}{c}\text { nu } \\
ぬ \\
\text { 㾸 } \\
\text { to lie down, to go to bed }\end{array}$} \\
\hline \multicolumn{2}{|c|}{$\begin{array}{l}\text { nebusoku } \\
\text { ねぶそく } \\
\text { 寝不足 } \\
\text { lack of sleep }\end{array}$} & \multicolumn{2}{|c|}{$\begin{array}{l}\text { nekomu } \\
\text { ねこむ } \\
\text { 寝込む } \\
\text { to stay in bed }\end{array}$} & \multicolumn{2}{|c|}{$\begin{array}{c}\text { nereru } \\
\text { ねれる } \\
\text { 寝れる } \\
\text { to be able to sleep }\end{array}$} \\
\hline \multicolumn{3}{|c|}{$\begin{array}{c}\text { nekashitsukeru } \\
\text { ねかしつける } \\
\text { 寝かし付ける } \\
\text { to lull to sleep }\end{array}$} & \multicolumn{3}{|c|}{$\begin{array}{l}\text { jukusui } \\
\text { じゅくすい } \\
\text { 熟睡 } \\
\text { sound sleep }\end{array}$} \\
\hline \multicolumn{2}{|c|}{$\begin{array}{c}\text { nekasu } \\
\text { ねかす } \\
\text { 寝かす }\end{array}$} & \multicolumn{2}{|c|}{$\begin{array}{l}\underset{\text { ¿imin }}{\operatorname{eim}} \\
\text { えい } \\
\text { 永眠 }\end{array}$} & \multicolumn{2}{|r|}{$\begin{array}{l}\text { nemuraseru } \\
\text { ねむらせる } \\
\text { 眠らせる }\end{array}$} \\
\hline
\end{tabular}

Fig 3. Search in the search box. The figure was adapted from Akebi App on Aug 19th, 2018. 
In Handwriting, you can write down the kanji to be searched. No need to worry about the order of scratches, because this Akebi application can detect a starch depending on the shape and number of scratches. The disadvantages of this Handwriting is only Kanji letters that could be detected, whereas Hiragana-Katakana or Romaji letters could not be detected, as in Figure 4.

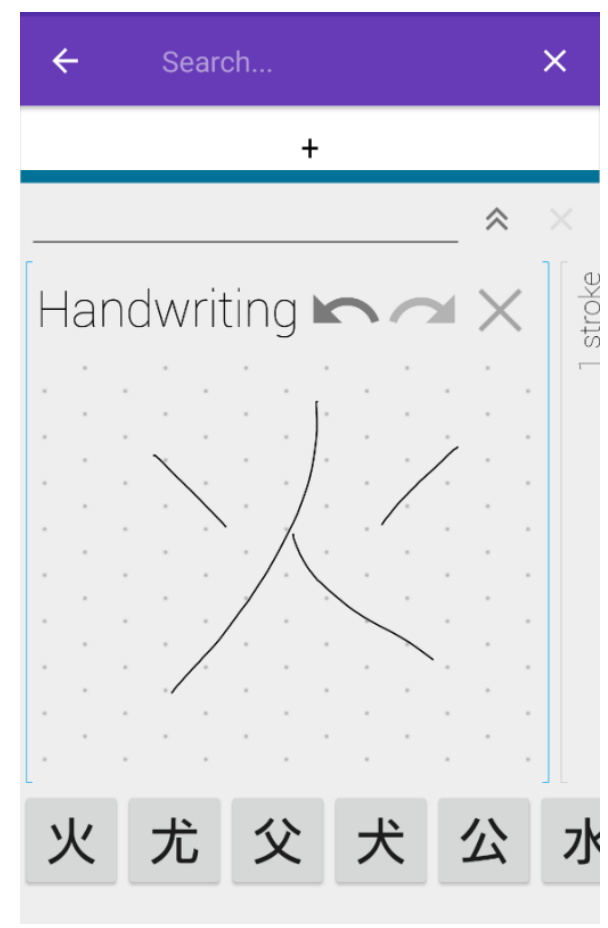

Fig 4. Use a Handwriting. The figure was adapted from Akebi App on Aug 19th, 2018.

Figure 5 shows the results of the starch that we are "search". There are displayed the meaning of kanji, how to read, and examples of words. 

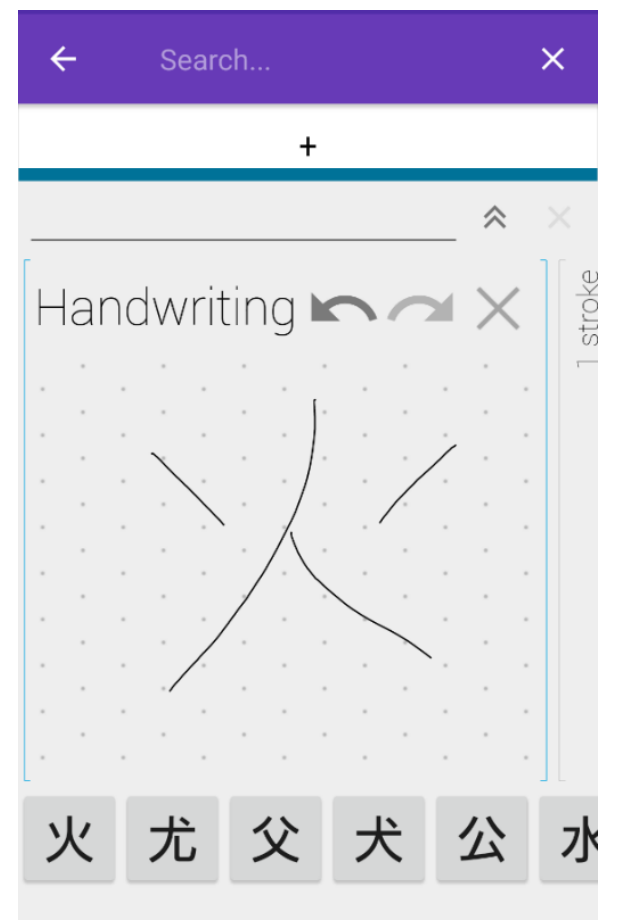

Fig 5. The result from "Handwriting". The figure was adapted from Akebi App on Aug 19th, 2018.

In addition to Kanji, there are also features that show examples sentence based on the search term. This aims to make it easier for users to understand the meaning of the word. Because in Japanese, several words have many meanings, this Akebi application can make it easier for us to match the word with different sentences. For Kanji Verb, in the example sentence there is an example of the verb's change depending on the sentence.

Figure 6 shows that we can search for words in Japanese using their meaning in English. After pressing "enter", you will see the word in question along with the example sentence in Figure 7. 


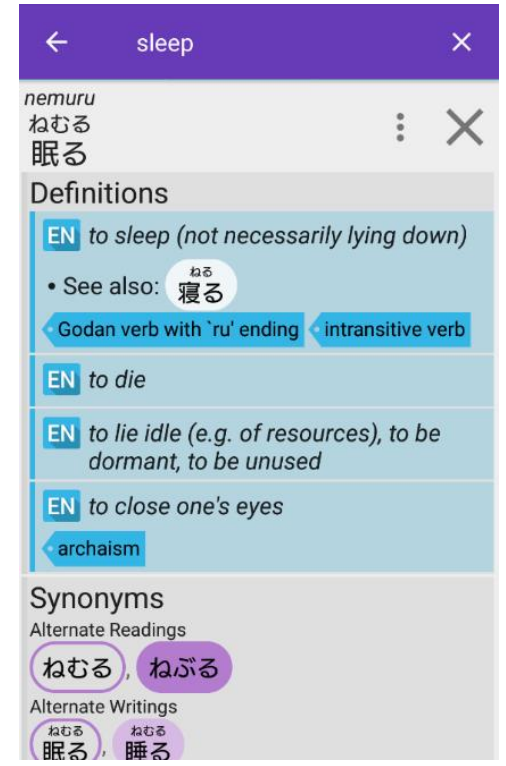

Fig 6. Search definition. The figure was adapted from Akebi App on Aug 19th, 2018.

\begin{tabular}{|c|c|}
\hline$\leftarrow$ & sleep \\
\hline \multicolumn{2}{|c|}{$\begin{array}{l}\text { Examples } \\
\text { Following は (18.7\%) }\end{array}$} \\
\hline \multicolumn{2}{|c|}{ 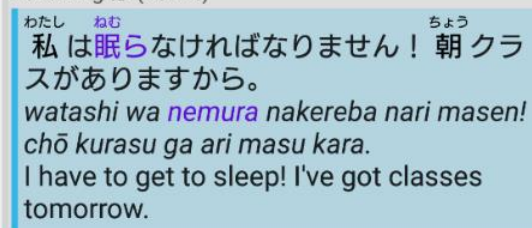 } \\
\hline \multicolumn{2}{|c|}{ Following ぐっすり $(7.5 \%)$} \\
\hline \multicolumn{2}{|c|}{$\begin{array}{l}\text { タ̃ } \\
\text { ダへははぐっすり眠れたよ。 } \\
\text { yūbe wa gussuri nemureta yo. } \\
\text { I slept so well last night. } \\
\text { I slept very well last night. } \\
\text { I slept soundly last night. }\end{array}$} \\
\hline \multicolumn{2}{|c|}{ Following で (7.5\%) } \\
\hline \multicolumn{2}{|c|}{ 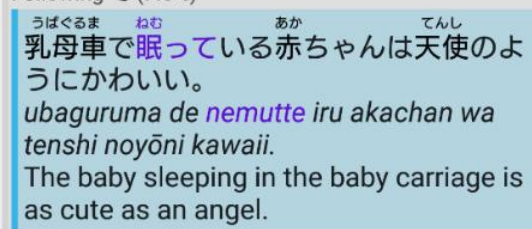 } \\
\hline
\end{tabular}

Fig 7. Example Sentence. The figure was adapted from Akebi App on Aug 19th, 2018. 
For the List feature, users can enter the Kanji that they want to enter in the list so that when they want to search for that word the user does not need to look for the word itself because it is already in the list. In the Kanji Grid feature, users can test the memorization skills of Kanji letters based on their level starting from the level of N5, N4, N3, N2, N1 and so on. With this feature, users can evaluate themselves against the material that has been learned before. If the user is a beginner in using the Akebi application, there is a tutorial feature that guides us to use a good and right application. Akebi provides a Feedback feature so users can assess the application so that it can improve the performance of the application's performance.

\section{Conclusion}

Indonesian population cannot be separated from the use of IT, which increases rapidly every year. Therefore, the development of IT is widely used by people to create a site or application that helps us every day. Included with the learning application for both students and teachers. The application certainly has advantages and disadvantages, but surely it will be developed so that the application can be optimized properly.

\section{References}

[1] Alliance, O. H.: Android overview. Open Handset Alliance, 8, 88-91. (2011).

[2] Manjoo, F.: A murky road ahead for Android, despite market dominance. The New York Times, 28. (2015).

[3] Soegoto, E. S.: Entrepreneurship Menjadi Pebisnis Ulung. Elex Media Komputindo. (2013).

[4] bin Hanafi, H. F., Said, C. S., Ariffin, A. H., Zainuddin, N. A., \& Samsuddin, K.: Using a collaborative Mobile Augmented Reality learning application (CoMARLA) to improve Improve Student Learning. In IOP Conference Series: Materials Science and Engineering (Vol. 160, No. 1, p. 012111). IOP Publishing. (2016).

[5] Larson, E. M.: Programming a Website to Purchase Online with a Texting Method. (2016).

[6] Riadh, M. H.: Notification System to Students using an Android Application. International Journal of Computer Applications, 975, 8887. (2016).

[7] Ma, L., Gu, L., \& Wang, J.: Research and development of mobile application for android platform. International journal of multimedia and ubiquitous engineering, 9(4), 187-198. (2014).

[8] de Clunie, G. T., Serrão, T., Gómez, B., Riley, J., Crespo, S., Rangel, N., ... \& de Barraza, O.: Developing an Android based learning application for mobile devices. In Proceedings of the 6th Euro American Conference on Telematics and Information Systems (pp. 239-245). ACM. (2012).

[9] Arista, F. S., \& Kuswanto, H.: Virtual Physics Laboratory Application Based on the Android Smartphone to Improve Learning Independence and Conceptual Understanding. International Journal of Instruction, 11(1), 1-16. (2018).

[10] Jamatia, R., \& Das, S.: 'Rwngmari: An Android Based Learning App for Kokborok Language'. International Journal of Computational Intelligence \& IoT, 1(1). (2018).

[11] Tamhane, K. D., Khan, W. T., Tribhuwan, S. R., Burke, A. P., \& Take, S. B.: Mobile learning application. International Journal of Scientific and Research Publications, 5(3), 1-4. (2015).

[12] El-Sofany, H. F., El-Seoud, S. A., Alwadani, H. M., \& Alwadani, A. E.: Development of Mobile Educational Services Application to Improve Educational Outcomes using Android Technology. International Journal of Interactive Mobile Technologies (iJIM), 8(2), 4-9. (2014). 